\title{
ANALISIS KESULITAN PEMBELAJARAN TEMATIK PADA SISWA KELAS IV SEKOLAH DASAR NEGERI
}

\author{
Anggia Jelita ${ }^{1}$, Elpri Darta Putra ${ }^{1}$ \\ ${ }^{1}$ Universitas Islam Riau, Indonesia \\ *Corresponding Address: anggiajelita1109@gmail.com
}

Naskah diterima: 6 Agustus 2021| Disetujui: 30 Agustus 2021 | Diterbitkan: 1 September 2021

\begin{abstract}
This type of research is descriptive qualitative research. Sources of data in this study were fourth grade teachers and 6 fourth grade students at SDN 014 Binjai Island. Data collection techniques used are interviews, observation and documentation. The data analysis technique uses the Milles and Huberman model with stages, data reduction, data presentation, and drawing conclusions. The results showed that there were six thematic learning difficulties in grade IV students, namely, 1) students felt confused, 2) students who had low cognitive/thinking power were left behind, 3) were less than optimal in receiving lessons, 4) parents had difficulties when helping. children study at home 5) students get low scores, and 6) students feel bored. While the difficulty factors that affect thematic learning difficulties at SDN 014 Binjai Island are eight, namely 1) lots of and mixed materials, 2) student learning styles, 3) HR (Human Resources), 4) student age, 5) thinking power. or students' cognitive, 6) parents, 7) long learning time, and 8) classroom atmosphere. The conclusion in this study is that there are still difficulties experienced by students related to thematic learning, this is due to a lot of influencing factors.
\end{abstract}

Keywords: Difficulty, Thematic Learning, Students, Elementary School

Abstrak: Penelitian ini bertujuan untuk mendeskripsikan kesulitan pembelajaran tematik dan mendeskripsikan faktor-faktor yang mempengaruhi kesulitan pembelajaran tematik pada siswa kelas IV SDN 014 Pulau Binjai. Jenis penelitian ini adalah kualitatif deskriptif. Sumber data pada penelitian adalah guru kelas IV serta 6 siswa kelas IV di SDN 014 Pulau Binjai. Teknik pengumpulan data yang digunakan adalah wawancara, observasi dan dokumentasi. Teknik analisis data menggunakan model Milles and Huberman dengan tahapan, reduksi data, penyajian data, dan penarikan kesimpulan. Hasil penelitian menunjukkan bahwa kesulitan-kesulitan pembelajaran tematik pada siswa kelas IV ada enam yaitu, 1) siswa kebingungan, 2) siswa yang memiliki daya fikir rendah jadi ketinggalan, 3) penerimaan pelajaran kurang maksimal, 4) orang tua menjadi kesulitan ketika mengajari anak dirumah 5) nilai siswa menjadi rendah, dan 6) siswa menjadi bosan. Sedangkan faktor-faktor kesulitan yang mempengaruhi kesulitan pembelajaran tematik di SDN 014 Pulau Binjai ada delapan yaitu 1) banyak materi dan campur, 2) model belajar siswa, 3) SDM (Sumber Daya Manusia),4) umur siswa,5) kekuatan berfikir siswa, 6) orang tua, 7) waktu belajar yang lama, dan 8) suasana/kondisi kelas. Kesimpulannya, masih terdapat kesulitan yang dialami siswa terkait pembelajaran tematik, hal tersebut disebabkan banyak sekali faktor-faktor yang mempengaruhi.

Kata kunci: Kesulitan, Pembelajaran Tematik, Siswa, SD 


\section{PENDAHULUAN}

Pendidikan adalah usaha sadar dan bertujuan untuk mengembangkan kualitas manusia sebagai suatu kegiatan yang sadar akan tujuan. Maka dalam pelaksanaannya berada dalam suatu proses yang berkesinambungan dalam setiap jenis dan jenjang pendidikan, semuanya berkaitan dalam suatu sistem pendidikan yang integral. Pendidikan di Indonesia di selenggarakan melalui jalur, jenjang dan jenis pendidikan (Artapati \& Budiningsih, 2018). Jalur pendidikan adalah wahana yang harus dilalui peserta didik agar dapat mengembangkan potensi dirinya dalam suatu proses pendidikan yang sesuai dengan tujuan pendidikan. Terdapat tiga jalur pendidikan yaitu jalur pendidikan formal, non formal, dan informal. Pendidikan formal tidak terlepas dari kurikulum maupun pembelajaran. Menurut UU RI Nomor 20 Tahun 2003 tentang Sistem Pendidikan Nasional pasal 1 ayat 19, kurikulum adalah seperangkat rencana dan pengaturan mengenai tujuan, isi, dan bahan pelajaran serta cara yang digunakan sebagai acuan dalam penyelenggaraan kegiatan pembelajaran untuk mencapai tujuan pendidikan (Mulyasa, 2016). Kurikulum yang digunakan saat inilah adalah kurikulum 2013. Kurikulum 2013 menurut (Imas Kurniasih, 2014) merupakan kurikulum yang didalam proses pembelajarannya menekankan penggunaan pendekatan saintifik/ilmiah, penilaian autentik serta pembelajaran tematik integratif. Melalui penerapan kurikulum ini diharapkan dapat mencetak generasi Indonesia yang kreatif serta kritis sesuai dengan tuntutan zaman.

Sejalan pengertian kurikulum di atas, kurikulum 2013 merupakan pengganti dari kurikulum sebelumnya (KTSP). Ciri khas kurikulum 2013 dapat dilihat dari pembelajaran yang tematik integratif, pendekatan saintifik, serta penilaian menggunakan pendekatan otentik (Kamiludin \& Suryaman, 2017). Salah satu penekanan dari kurikulum 2013 adalah pembelajaran tematik integratif. Pembelajaran tematik adalah pembelajaran terpadu yang menggunakan tema dalam memadukan beberapa mata pelajaran sehingga menghasilkan pengalaman yang lebih bermakna kepada peserta didik. Keterpaduan berdasarkan tema sama saja seperti menghubungkan persoalan satu dengan persoalan lainnya, sehingga terbentuklah kesatuan pengetahuan. Integrasi dalam kegiatan pembelajaran diharapkan mampu melahirkan pemahaman yang komprehensif pada diri peserta didik serta lingkungannya (Kunandar, 2015). Kegiatan pembelajaran tematik lebih menekankan pada keterlibatan peserta didik dalam proses belajar secara aktif, sehingga peserta didik memperoleh pengalaman langsung serta terlatih dalam menemukan sendiri berbagai pengetahuan. Dari pengalaman langsung peserta didik akan memahami konsep yang sedang mereka pelajari dan akan mampu menghubungkan dengan konsep yang telah mereka pahami. (Syarifudin, 2020)

Berdasarkan penekanan dari kurikulum 2013 yaitu pembelajaran tematik integratif, maka diharapkan proses pembelajaran yang dilakukan dapat memberikan pengalaman belajar yang lebih 
bermakna kepada siswa. Akan tetapi, pada kenyataannya penerapan pembelajaran tematik tidak selalu berjalan dengan baik. Karena masih banyak siswa yang mengalami kesulitan belajar pada pembelajaran tematik. Hal ini dikarenakan pada saat pembelajaran tematik, tidak semua siswa memahami semua materi yang diajarkan serta dapat membeda-bedakan setiap materi yang dipadukan jika guru tidak menyampaikan mata pelajaran apa yang sedang dipelajari. Tidak hanya itu, pada pembelajaran tematik sering dijumpai permsaalahan yang menjadi kendala dalam belajar yang disebabkan adanya keanekaragaman individu siswa. Oleh karena itu, penguasaan hasil belajar berbeda, maka akan berbeda pula ketuntasan hasil belajar mereka, baik siswa yang cepat dalam proses belajarnya maupun yang lambat.

Kesulitan belajar sebagai suatu gejala yang nampak pada peserta didik yang ditandai dengan adanya hasil belajar yang rendah atau dibawah norma yang telah ditetapkan (Anzar \& Mardhatillah., 2017). Kesulitan belajar biasanya tidak dapat diidentifikasi sampai anak mengalami kegagalan dalam menyelesaikan tugas-tugas akademik yang harus dilakukannya (Hidayah et al., 2015). Kesulitan belajar ini merupakan gangguan yang secara nyata ada pada anak yang terkait dengan tugas umum dan khusus, yang diduga disebabkan karena faktor disfungsi neurologis, proses psikologis, maupun sebab-sebab lainnya sehingga anak yang berkesulitan belajar dalam suatu kelas menunjukkan prestasi belajar rendah (Yeni \& Almuslim, 2015).

Berdasarkan studi pendahuluan awal peneliti di kelas IV SDN 014 Pulau Binjai, diperoleh informasi bahwa hasil belajar siswa kelas IV masih dapat dikatakan rendah. Hal ini dilihat dari hasil belajar siswa selama proses pembelajaran berlangsung pada saat pembelajaran tematik. Hal ini dikarenakan bahwa saat pembelajaran tematik waktu pembelajaran terlalu singkat, minat belajar siswa yang masih sangat rendah, dan siswa lebih suka bermain serta menggangu temannya pada saat proses pembelajaran. Berdasarkan hasil wawancara dengan salah satu siswa yang mendapatkan nilai terendah, diperoleh informasi bahwa faktor penyebab siswa mendapatkan nilai rendah adalah karena pada saat kegiatan pembelajaran, siswa tidak mengetahui dan sulit membedakan mata pelajaran apa yang sedang dipelajari.

Berdasarkan permasalahan di atas, peneliti tertarik ingin melakukan peneliti dengan rumusan masalah yaitu apa saja kesulitan-kesulitan siswa pada pembelajaran tematik dikelas IV SDN 014 Pulau Binjai?, dan apa saja faktor-faktor kesulitan siswa pada pembelajaran tematik di kelas IV SDN 014 Pulau Binjai?. Tujuan dilakukannya penelitian ini adalah untuk mendeskripsikan kesulitan-kesulitan serta faktor-faktor kesulitan siswa pada pembelajaran tematik di kelas IV SDN 014 Pulau Binjai. 


\section{METODE}

Penelitian ini merupakan penelitian kualitatif dengan pendekatan deskriptif. Karaktersitik penelitian deskriptif kualitatif yaitu untuk mengeksplor suatu permasalahan atau fenomena sosial serta mengembangkan pemahaman yang spesifik dari suatu fenomena yang diteliti (Dafit \& Ramadan, 2020). Subjek pada penelitian ini adalah guru kelas IV serta 6 siswa kelas IV di SDN 014 Pulau Binjai Kecamatan Kuantan Mudik, Kabupaten Kuantan Singingi. Teknik pengambilan subjek yaitu teknik purposive sampling. Teknik purposive sampling merupakan teknik pengambilan sampel data dengan pertimbangan tertentu (Sugiyono, 2017).

Pada penelitian ini, data didapatkan berdasarkan hasil observasi, wawancara, dan analisis dokumen. Peneliti melakukan wawancara dengan guru kelas IV serta 6 siswa kelas IV SDN 014 terkait kesulitan pembelajaran tematik pada siswa kelas IV SDN 014 Pulau Binjai. Setelah peneliti melakukan kegiatan wawancara, peneliti melakukan kegiatan observasi. Kegiatan observasi dilakukan 3 kali selama proses pembelajaran. Peneliti mengikuti kegiatan belajar mengajar di dalam kelas IV dari awal sampai akhir pembelajaran. Peneliti juga melakukan analisis dokumen seperti RPP, silabus, buku guru dan buku siswa serta buku latihan siswa. Data yang telah dikumpulkan melalui teknik wawancara, observasi, serta analisis dokumen selanjutnya dianalisis. Pada penelitian ini, untuk menganalisis data peneliti menggunakan model Milles and Huberman dengan 3 tahapan yaitu reduksi data, penyajian data, dan penarikan kesimpulan.

\section{HASIL DAN PEMBAHASAN}

Penelitian ini dilakukan di kelas IV SDN 014 Pulau Binjai Kecamatan Kuantan Mudik, Kabupaten Kuantan Singingi. Pada saat peneliti melakukan penelitian, kegiatan belajar mengajar sudah dilaksanakan offline tidak online. Akan tetapi, guru dan siswa tetapi diminta untuk mematuhi protokol kesehatan seperti menjaga jarak, mencuci tangan dan selalu menggunakan masker. Penelitian ini dilakukan untuk mendeskripsikan kesulitan pembelajaran tematik pada siswa kelas IV serta faktor-faktor yang mempengaruhi kesulitan belajar siswa pada pembelajaran tematik di kelas IV SDN 014 Pulau binjai. Berikut merupakan penjelasan lebih rinci terkait data-data yang peneliti temukan dilapangan.

\section{Deskripsi Data Kesulitan Pembelajaran Tematik Pada Siswa Kelas IV SDN 014 Pulau Binjai}

Dalam perkembangannya, SDN 014 Pulau Binjai selalu berusaha meningkatkan kemampuan siswa dan mengikuti program pendidikan dan mengikuti kurikulum sesuai dengan kurikulum yang telah ditetapkan di Indonesia. Saat ini pendidikan di Indonesia menggunakan Kurikulam 2013. Dalam kurikulum ini, program pembelajaran yang digunakan adalah pembelajaran tematik. Sedangkan 
pelajaran tematik merupakan pembelajaran baru yang didalamnya terdapat berbagai materi pelajaran yang dapat menjadi masalah bagi siswa dalam pembelajaran tematik (Wahyuni et al., 2016).

Dalam proses pembelajaran tematik di kelas IV SDN 014 Pulau Binjai, yang baru diterapkan pada tahun 2019 tentunya ada kesulitan yang dialami ketika siswa sedang belajar. Berdasarkan hasil wawancara dengan guru kelas IV, diperoleh informasi bahwa kesulitan pada pembelajaran tematik yaitu siswa kebingungan karena dalam satu sub tema ada campuran beberapa pelajaran, siswa yang mempunyai kognitif atau daya berfikir rendah akan ketinggalan, siswa memiliki persepsi bahwa tematik adalah pelajaran baru sehingga kurang maksimal dalam menerima materi, dan orang tua kesulitan ketika anak membutuhkan bantuannya dalam belajar. Berikut merupakan data-data kesulitan siswa pada pembelajaran tematik di SDN 014 Pulau Binjai yang didapatkan melalui hasil wawancara dengan 6 siswa yang mengalami kesulitan pada pembelajaran tematik yang dilihat dari nilai terendah yang didapatkan selama proses pembelajaran tematik.

Tabel 1. Hasil wawancara dengan siswa mengenai kesulitan-kesulitan siswa pada pembelajaran tematik.

\begin{tabular}{|c|c|c|}
\hline No & Nama Siswa & Kesulitan-kesulitan siswa pada pembelajaran tematik \\
\hline 1. & AN & $\begin{array}{l}\text { Kesulitan siswa yaitu ketikan pembelajaran tematik AN mengalami } \\
\text { masalah dan kesulitan pada materi menggambar sampul buku dan materi } \\
\text { PPKN. }\end{array}$ \\
\hline 2. & FN & $\begin{array}{l}\text { FN kesulitan ketika mengerjakan soal yang sulit dan ketika FN tidak } \\
\text { memahami penjelasan dari guru. }\end{array}$ \\
\hline 3. & $\mathrm{RN}$ & $\begin{array}{l}\text { Kesulitan RN adalah RN mengatakan bahwa RN tidak suka } \\
\text { tematik karena bingung dan sulit, dan } \mathrm{RN} \text { selalu mendapatkan nilai jelek } \\
\text { ketika tidak dapat mengerjakan soal-soal yang sulit. }\end{array}$ \\
\hline 4. & FR & $\begin{array}{l}\text { FR kesulitan ketika dituntut untuk memahami banyak materi dalam satu } \\
\text { hari. Sehingga FR tidak bisa menjawab soal pada saat ulangan. }\end{array}$ \\
\hline 5. & $\mathrm{RF}$ & $\begin{array}{l}\text { Kesulitan yang dialami RF pada saat pembelajaran tematik adalah RF } \\
\text { merasa bosan dikarenakan dalam satu waktu RF harus memahami banyak } \\
\text { materi yang berbeda-beda. Sehingga RF sering kebalik setiap mengingat } \\
\text { materi yang sudah diajarkan. }\end{array}$ \\
\hline 6. & SS & $\begin{array}{l}\text { Kesulitan SS pada pembelajaran tematik adalah SS sulit membedakan } \\
\text { setiap materi pada saat pembelajaran tematik. SS sulit membedakan } \\
\text { antara materi Bahasa Indonesia serta IPA dan IPS. SS sulit untuk } \\
\text { mengingat materi yang diajarkan, sehingga nilai SS rendah ketika guru } \\
\text { memberikan latihan atau ulangan. }\end{array}$ \\
\hline
\end{tabular}


Kesulitan yang dihadapi oleh 6 siswa tersebut diperkuat dari hasil obervasi dan pengamatan peneliti, siswa tersebut lebih banyak diam, siswa hanya bisa mendengarkan, namun tidak memahami apa yang disampaikan oleh guru dan masih terlihat bingung ketika menjawab soal atau menulis jawaban yang telah dibacakan oleh guru. Kesulitan berikutnya yaitu pada konsentrasi belajar siswa. Ada beberapa siswa yang mulai ramai, sehingga konsentrasi belajarnya menjadi turun. Kesulitan pada pembelajaran tematik tidak hanya terjadi pada satu atau dua siswa, namun hampir setiap siswa. Kesulitan berikutnya adalah siswa mulai bosan di kelas dan tidak mendengarkan guru karena jam pelajaran tematik lebih banyak dari pelajaran yang lainya.

Kesulitan berikutnya adalah siswa bingung karena pelajaran tematik terdiri dari banyak materi. Siswa yang mempunyai kognitif atau daya berfikir rendah menjadi ketinggalan, kurang maksimal dalam menerima pelajaran karena menjadi pelajaran yang baru, orang tua kesulitan ketika anak meminta bantuan saat belajar dirumah, siswa sulit memahami dan menjwab, nilai siswa ada yang jelek, dan siswa merasa bosan karena waktu pelajaran tematik yang lebih lama daripada pelajaran yang lainnya.

\section{Deskripsi Data Faktor-faktor Kesulitan Pada Pembelajaran Tematik Di SDN 014 Pulau Binjai}

Kesulitan yang dihadapi siswa pada saat pembelajaran tematik di kelas IV SDN 014 Pulau Binjai sangatlah banyak. Dari kesulitan tersebut tentunya terdapat faktor yang mempengaruhi terjadinya kesulitan belajar tematik siswa. Berdasarkan hasil wawancara dengan guru kelas IV, mengatakan bahwa faktor yang mempengaruhi kesulitan siswa pada pembelajaran temati di kelas IV yaitu karena materi tematik banyak dan bercampur, perbedaan gaya belajar siswa jika disekolah lain kemungkinan siswanya ada tambahan les, sedangkan di sekolah terebut belum semua mengikuti les di luar sekolah.

Faktor kesulitan selanjutnya berdasarkan hasil wawancara dengen guru kelas IV, yaitu pertama, siswa yaitu SDM (Sumber Daya Manusia) yang menonjol yang dapat dilihat dari keseharian dan belajar siswa, usia siswa, dan kemampuan berfikir siswa atau kognitif yang berbeda- beda. Kedua, yaitu orang tua, sebagian orang tua siswa tidak mampu memberi arahan atau bantuan ketika anak belajar dirumah, sehingga anak hanya belajar semampunya dan semaunya. Berdasarkan hasil wawancara dengan siswa, diperoleh informasi bahwa faktor-faktor yang mempengaruhi kesulitan siswa pada pembelajaran tematik di kelas IV SDN 014 Pulau Binjai sebagai berikut : 
Tabel 2. Hasil wawancara siswa mengenai faktor-faktor kesulitan siswa pada pembelajaran tematik.

\begin{tabular}{|c|c|c|}
\hline No & Nama Siswa & Faktor Kesulitan siswa pada Pembelajaran Tematik \\
\hline 1. & AN & $\begin{array}{l}\text { Faktor waktu yang lama membuat jenuh dan malas ketika } \\
\text { belajar tematik, sehingga dalam pembelajaran siswa tidak } \\
\text { menerima pelajaran dengan baik }\end{array}$ \\
\hline 2. & FN & $\begin{array}{l}\text { Materi yang banyak. Dalam setiap sub bab dalam buku tematik } \\
\text { terdiri dari banyak materi, sehingga siswa mempunyai } \\
\text { problematika dalam belajar seperti bingung dan tidak mudah } \\
\text { paham. }\end{array}$ \\
\hline 3. & $\mathrm{RN}$ & $\begin{array}{l}\text { Suasana kelas yang semakin lama pembelajarannya, semakin } \\
\text { gaduh, siswa asyik bernain dan ramai sendiri dengan temannya. }\end{array}$ \\
\hline 4. & FR & $\begin{array}{l}\text { Banyak nya materi yang harus dipahami setiap harinya, } \\
\text { sehingga siswa merasa kesulitan untuk mengingat. }\end{array}$ \\
\hline 5. & $\mathrm{RF}$ & Waktu yang sedikit akan tetapi materi banyak. \\
\hline 6. & SS & $\begin{array}{l}\text { Mata pelajaran yang harus dipahami setia harinya begitu banyak } \\
\text { akan tetapi waktunya sedikit. }\end{array}$ \\
\hline
\end{tabular}

Berdasarkan hasil penelitian, maka akan dibahas lebih lanjut terkait kesulitan pada pembelajaran tematik pada siswa kelas IV SDN 014 Pulau Binjai. Berikut merupakan penjelasan lebih rinci terkait pembahasan dari hasil penelitian.

\section{Kesulitan Pembelajaran Tematik Pada Siswa Kelas IV SDN 014 Pulau Binjai}

Pembelajaran tematik terpadu merupakan salah satu model pembelajaran terpadu (integrated instruction) yang merupakan suatu sistem pembelajaran dan memungkinkan siswa secara individu maupun kelompok, aktif menggali, dan menemukan konsep dan prinsip-prinsip keilmuan secara holistik, bermakna, serta autentik (Muhith, 2018). Akan tetapi, di dalam pelaksanaannya tidak semua berjalan dengan baik. Masih banyak siswa yang mengalami kesulitan pada pembelajaran tematik. Di SDN 014 Pulau Binjai, kesulitan pada pembelajaran tematik yang dialami siswa kelas IV di SDN 014 Pulau Binjai yaitu sebagai berikut:

1. Siswa merasa bingung

Hal ini karena banyak materi dalam satu tema yang memuat banyak materi pelajaran seperti PJOK, Matematika, Kewarganegaraan, Seni Budaya dan lain-lain. Contohnya ketika siswa kesulitan mempelajari organ pernafasan, sebagian siswa merasa menggambar adalah hal yang sulit. 
2. Siswa yang memiliki kognitif atau daya fikir rendah menjadi tertinggal.

Kognitif adalah kemampuan berfikir yang dimiliki oleh seorang anak. Anak yang mampu atau tidak menerima dengan baik suatu pelajaran tematik akan lebih cepat paham dan memiliki kognitif dan daya fikir yang baik. Sedangkan anak yang memiliki kognitif atau daya fikir rendah akan menjadi tertinggal (Kognitif, 2016).

3. Siswa menerima pelajaran kurang maksimal

Hal ini karena di SDN 014 Pulau Binjai menjadi mata pelajaran baru, sehingga siswa perlu adaptasi dengan pelajaran sehingga belum terbiasa dan kurang maksimal.

4. Orang tua merasa kesulitan ketika anak meminta bantuan saat belajar dirumah

Hal ini karena pembelajaran tematik bukan hanya pelajaran yang soal dan jawaban hanya didalam buku akan tetapi harus bisa berfikir dan menganalisa, sehingga ketika belajar dirumah orang tua harus mampu membantu menyelesaikan apa yang ditugaskan guru (PR).

5. Siswa mendapatkan nilai yang tidak bagus

Hal ini disebabkan daya fikir yang berbeda dan materi tematik yang banyak dan sulit, karena tidak semua anak mudah memahami pelajaran tematik sehingga berdampak pada nilai pelajaran anak. Hal ini sesuai dengan pernyataan bahwa setiap individu memiliki tahapan perkembangan yang berbeda dengan orang lain. Setiap tahapan perkembangan akan dilalui oleh seorang individu secara berkesinambungan. Teori pentahapan ini merupakan teori yang banyak dianut oleh para ahli psikologi perkembangan (Rosalin, 2008).

6. Siswa merasa bosan

Hal ini disebabkan pelajaran tematik memiliki jam pelajaran yang lama dari mata pelajaran yang lainnya. Hal ini sesuai dengan pernyataan bahwa pelaksanaan pembelajaran tematik setiap hari dilakukan dengan menggunakan tiga tahapan kegiatan yaitu kegiatan pembukaan/awal/pendahuluan, kegiatan inti, dan kegiatan penutup (Haji, 1993). Alokasi waktu untuk setiap tahapan adalah kegiatan pembukaan kurang lebih satu jam pelajaran (1 x 30 menit), kegiatan inti 3 jam pelajaran $(3 \times 30$ menit) dan kegiatan penutup satu jam pelajaran (1 x 30 menit).

Kesulitan belajar dapar diartikan sebagai suatu kondisi atau tingkah laku yang mengalami hambatan dalam mencapai suatu perubahan baik berbentuk sikap, pengetahuan, maupun keterampilan (Pratiwi \& Ariawan, 2017). Kesulitan dalam pembelajaran tematik menjadi masalah yang menonjol bagi siswa. Banyak yang merasa kesulitan dan mendapatkan nilai yang rendah, sehingga kesulitan materi menjadi hal yang perlu diselesaikan oleh guru. Materi dalam teori dijelaskan bahwa pelajaran 
yang digunakan adalah penggabungan semua materi yang terdiri dari lima pelajaran yaitu pelajaran IPA dan IPS, Bahasa Indonesia, Matematika, PPKN. Dalam pembelajaran ini materi disajikan dalam fokus tema tertentu yang di dalamnya berisi penggabungan beberapa mata pelajaran. Tema itulah yang dipelajari dari berbagai sisi pandang dengan menggunakan informasi yang ada dalam sejumlah mata pelajaran, sehingga pengetahuan siswa atas tema tersebut bisa lebih lengkap. Isi mata pelajaran yang akan dibahas disesuaikan hubungannya dengan tema. Dengan demikian sekat-sekat mata pelajaran melebur dalam satu tema (Yulyani et al., 2020).

Berdasarkan sajian diatas dapat disimpulkan bahwa kesulitan pembelajaran tematik siswa kelas IV di SDN 014 Pulau Binjai ada enam yaitu 1) siswa kebingungan, 2) siswa yang mempunyai kognitif/daya fikir rendah akan ketinggalan, 3) kurang maksimal menerima pelajaran, 4) orang tua kesulitan ketika mendampingi belajar anak dirumah 5) siswa mendapat nilai rendah, dan 6) siswa merasa bosan.

\section{Faktor-Faktor Kesulitan Pada Pembelajaran Tematik Siswa Kelas IV SDN 014 Pulau Binjai}

Pembelajaran adalah suatu tujuan pendidikan. Hasilnya tergantung bagaimana proses belajar yang di alami murid sebagai anak didik. Dalam proses belajar dan pembelajaran ada berbagai kesulitan yang disebabkan oleh faktor-faktor yang mengakibatkan terjadinya permasalahan (Pane \& Darwis Dasopang, 2017). Berdasarkan pada hasil penelitian di SDN 014 Pulau Binjai, diperoleh informasi bahwa faktor-faktor kesulitan pembelajaran tematik siswa kelas IV SDN 014 Pulau Binjai yang didapat dari observasi dan wawancara sebagai berikut:

\section{Materi yang banyak dan bercampur}

Hal ini yang membuat siswa kebingungan dalam proses belajar tematik. Materi pembelajaran tematik adalah menggabungkan antara berbagai mata pelajaran sehingga siswa harus bisa menerima berbagai mata pelajaran dalam satu waktu pembelajaran. Hal ini sesuai dengan pengertian pembelajaran tematik itu sendiri. Setiawan menyatakan bahwa pembelajaran tematik sebagai suatu pendekatan belajar mengajar yang melibatkan beberapa mata pelajaran dalam satu tema untuk memberikan pengalaman bermakna bagi siswa. Pengalaman bermakna maksudnya anak memahami konsep-konsep yang telah mereka pelajari itu melalui pengalaman langsung dan menghubungkannya dengan konsep lain yang sudah mereka pahami (Setiawan, 2019).

\section{Gaya Belajar Siswa}

Gaya belajar siswa merupakan salah satu pengaruh dalam kesulitan siswa. Gaya belajar siswa yang bermacam-macam akan mempengaruhi proses belajar siswa dikelas. Jika siswa yang rajin belajar akan mudah memahami dan menyerap apa yang telah disampaikan oleh guru. Belajar 
merupakan merupakan proses perubahan yang terus menerus dalam diri individu yang tidak ditentukan oleh unsur keturunan, tetapi lebih banyak ditentukan oleh faktor-faktor dari luar (eksternal) (W, 2013). Jadi telah disebutkan bahwa faktor yang mempengaruhi kesulitan belajar paling banyak dari luar siswa, hal ini sama terlihat pada kesulitan pembelajaran tematik yang pengaruhnya adalah gaya belajar siswa.

Sumber Daya Manusia (SDM) adalah suatu proses peningkatan kualitas atau kemampuan manusia dalam rangka mencapai suatu pembangunan bangsa, sedang secara mikro pengembangan sumber daya manusia adalah suatu proses perencanaan pendidikan dan pelatihan serta pengelolaan tenaga atau karyawan untuk mencapai hasil optimum. Sekalipun peningkatan sumber daya aparatur reformasi melalui strategi learning organization (Maghfiroh et al., 2019). Faktor sumber daya manusia merupakan faktor yang menjadi perbedaan siswa di SDN 014 Pulau Binjai dengan siswa disekolah lain. Hal ini menjadi faktor yang mempengaruhi terjadinya kesulitan belajar siswa karena, kebanyaan siswa diluar selain disekolah, mereka juga mengkuti belajar non formal seperti Les atau mempunyai guru privat. Sedangkan di SDN 014 Pulau Binjai belum semua siswa mengikuti les dan memilki guru privat.

\section{Usia Siswa}

Faktor kesulitan pembelajarn tematik adalah umur siswa. Pembelajaran tematik merupakan pelajaran yang baru di SDN 014 Pulau Binjai yang dipelajari dari berbagai kalangan siswa. Usia siswa yang berbeda dalam satu kelas sangat berpengaruh saat pembelajaran tematik. Usia yang rendah memiliki daya tangkap yang kurang. Sehingga mempengaruhi belajarnya. Hal ini sesuai dengan pernyataan yang menyatakan bahwa hasil belajar anak dipengaruhi oleh faktor usia siswa (Hakim, 2011).

\section{Daya berfikir atau Kognitif Siswa}

Kognitif adalah suatu ranah psikologis manusia yang meliputi setiap perilaku mental yang berhubungan dengan pemahaman, pertimbangan, pengolahan informasi, pemecahan masalah, kesengajaan, dan keyakinan. Dalam teori lain kognitif adalah hasil dari hubungan perkembangan otak dan sistem saraf dengan pengalaman-pengalaman yang membantu individu untuk beradaptasi dengan lingkungan. Kognitif siswa menjadi faktor kesulitan belajar siswa karena setiap siswa memiliki daya berfikir, kemampuan menerima pelajaran, beradaptasi dengan hal baru yang berbeda. Hal ini sesuai dengan pernyataan yang menyatakan bahwa pembelajaran tematik merupakan palajaran yang cukup sulit, tetap akan diterima mudah oleh siswa yang memiliki daya ingat, daya berfikir yang tinggi. Sedangkan untuk siswa yang memiliki daya fikir rendah akan mengalami kesulitan dalam proses 
belajar dan akan menimbulakan problema, misal nilai kurang baik, tertinggal dan tidak menyukai pelajarannya (Rini Kristiantari, 2015).

\section{Orang Tua}

Proses perkembangan anak dan belajar anak tidak terlepas dari orang tua. Keluarga adalah sekolah pertama bagi anak-anak, dan orang tua sebagai panutan dan guru. Sekolah formal merupakan sekolah kelanjutan anak-anak untuk belajar, akan tetapi orang tua tetap menjadi patokan keberhasilan anak. Bergantinya kurikulum yang didalamnya terdapat pembelajaran tematik membuat semua pihak merasa menjadi hal yang baru, termasuk orang tua. Banyak Orang tua yang mengeluh merasa kesulitan ketika mengajari atau membantu anaknya belajar dirumah, sehingga orang tua membantu mengerjakan sebisanya. Hal ini sesuai dengan pernyataan yang meyatakan bahwa yang demikian menjadi kesulitan dalam belajar tematik karena orang tua belum maksimal dalam membantu membelajari anaknya dalam plajaran tematik dirumah dan anak hanya mengikuti apa yang sudah diajarkan (Hasbi, 2012).

\section{Waktu Pelajaran Yang Lama}

Waktu pembelajaran disekolah ialah waktu terjadinya proses belajar mengajar di sekolah. Waktu belajar disekolah dapat mempengaruhi prestasi belajar siswa. Apabila siswa masuk sekolah pada sore hari, sebenarnya kurang dapat dipertanggung jawabkan. Siswa yang seharusnya beristirahat, tetapi terpaksa masuk sekolah, hingga mereka mendengarkan pelajaran dengan mengantuk dan sebagainya. Sebaliknya siswa yang belajar dipagi hari, pikiran masih segar, jasmani dalam kondisi yang baik, sehingga siswa dapat menyerap materi dengan baik. Apabila kondisi badan siswa sudah lelah, akan mengalami kesulitan dalam menerima pelajaran. Kesulitan itu disebabkan karena siswa sukar berkonsentrasi dan berpikir pada kondisi badan yang lelah. Untuk itu memilih waktu pembelajaran disekolah yang tepat akan memberi pengaruh positif terhadap belajar siswa. Apabila belajar siswa baik, maka prestasi belajar siswa baik pula. Pembelajaran tematik memiliki waktu pelajaran lebih lama di banding dengan mata pelajaran yang lain. Dan hampir setia hari pelajaran tematik diberikan kepada siswa. Sehingga menjadi faktor problematika pembelajaran tematik, karena siswa sudah mulai bosan dan tidak berkonsentrasi lagi (Wahyono et al., 2020).

\section{Suasana Kelas}

Suasana kelas menjadi faktor kesulitan pembelajaran karena dalam pembelajaran tematik tidak semua siswa diam, memperhatikan guru maupun materinya. Sebagian siswa ada yang ramai, tertawa, sehingga suasana kelas menjadi tidak kondusif dan mempengaruhi proses pembelajaran khususnya pembelajaran tematik yang waktu belajarnya juga cukup lama. Hal ini sesuai dengan pernyataan yang 
menyatakan bahwa suasana kelas adalah kondisi atau keadaan yang terjadi di dalam kelas selama proses pembelajaran. Suasana kelas yang baik tentu akan menambah semangat peserta didik untuk mengikuti proses belajar mengajar. Interaksi guru dengan guru, siswa dengan siswa, dan siswa dengan guru juga sangat mempengaruhi suasana kelas (Sekolah \& Kejuruan, 2019).

Berdasarkan sajian di atas dapat disimpulkan bahwa faktor yang mempengaruhi problematika siswa dalam pembelajaran tematik siswa kelas IV MSDN 014 Pulau Binjai ada delapan, yaitu 1) materi yang banyak dan campur, 2) gaya belajar siswa, 3) SDM (Sumber Daya Manusia), 4) usia siswa, 5) daya berfikir atau kognitif siswa, 6) orang tua, 7) waktu pembelajaran yang lama, dan 8) suasana kelas.

\section{KESIMPULAN}

Kurikulum 2013 (K-13) adalah kurikulum yang berlaku dalam sistem pendidikan Indonesia. Kurikulum ini merupakan kurikulum tetap diterapkan oleh pemerintah untuk menggantikan Kurikulum-2006 (yang sering disebut sebagai Kurikulum Tingkat Satuan Pendidikan) yang telah berlaku selama kurang lebih 6 tahun. Kurikulum 2013 masuk dalam masa percobaanya pada tahun 2013 dengan menjadikan beberapa sekolah menjadi sekolah rintisan. Salah satu penekanan dari kurikulum 2013 adalah pembelajaran tematik integratif. Di SDN 014 Pulau Binjai, telah menerapkan kurikulum 2013 semenjak tahun 2018 yang penerapannya dilakukan secara bertahap. Di SDN 014 Pulau Binjai juga sudah menerapkan pembelajaran tematik. Pembelajaran tematik merupakan pembelajaran yang menjadikan tema sebagai pemersatu mata pelajaran. Akan tetapi, di dalam penerapan pembelajaran tematik, masih terdapat kesulitan-kesulitan yang dialami siswa selama proses pembelajaran tematik. Di SDN 014 Pulau Binjai diperoleh informasi bahwa terenamdapat 6 kesulitan pembelajaran tematik yang dialami siswa kelas IV SDN 014 Pulau Binjai, yaitu 1) siswa merasa bingung, 2) siswa yang memiliki kognitif/daya fikir rendah menjadi tertinggal, 3) kurang maksimal menerima pelajaran, 4) orang tua kesulitan ketika membantu belajar anak dirumah 5) siswa mendapat nilai rendah, dan 6) siswa merasa bosan. Dari kesulitan tersebut, terdapat delapan faktorfaktor yang mempengaruhi kesulitan pembelajaran tematik siswa kelas IV di SDN 014 Pulau Binjai, yaitu 1) materi yang banyak dan campur, 2) gaya belajar siswa, 3) SDM (Sumber Daya Manusia), 4) usia siswa, 5) daya berfikir atau kognitif siswa, 6) orang tua, 7) waktu pembelajaran yang lama, dan 8) suasana kelas. Berdasarkan hasil kajian tersebut, maka dapat ditarik kesimpulan bahwa masih banyak kesulitan serta faktor-faktor yang mempengaruhi kesulitan siswa pada pembelajaran tematik khususnya siswa kelas IV di SDN 014 Pulau Binjai. 


\section{DAFTAR PUSTAKA}

Anzar, S. Febri., \& Mardhatillah. (2017). Analisis Kesulitan Belajar Siswa pada Pembelajaran Bahasa Indonesia di Kelas V SD Negeri 20 Meulaboh Kabupaten Aceh Barat Tahun Ajaran 2015/2016. Bina Gogik, 4(1 Maret 2017), 53-64.

Artapati, L. W., \& Budiningsih, C. A. (2018). Pelaksanaan pembelajaran Kurikulum 2013 di SD Negeri Serayu Yogyakarta. Jurnal Inovasi Teknologi Pendidikan, 4(2), 185-200. https://doi.org/10.21831/jitp.v4i2.13016

Dafit, F., \& Ramadan, Z. H. (2020). Pelaksanaan Program Gerakan Literasi Sekolah (GLS) di Sekolah Dasar. Jurnal Basicedu, 4(4), 1429-1437. https://doi.org/10.31004/basicedu.v4i4.585

Haji, S. (1993). Pembelajaran Tematik Yang Ideal Di Sd/Mi. 6, 56-69.

Hakim, A. L. (2011). Pengaruh PAUD terhadap Prestasi Belajar Siswa kelas I SD di kab-kota Tangerang. Pedidikan Dan Kebudayaan, 17 (1).

Hasbi, W. (2012). Keluarga sebagai Basis Pendidikan Pertama dan Utama. Jurnal Ilmiah DIDAKTIKA, XII, $245-258$.

Hidayah, N., Pgmi, J., Tarbiyah, F., \& Keguruan, D. (2015). Tematik Sd. TERAMPIL Pendidikan Dan Pembelajaran Dasar, 2, 34-49.

Imas Kurniasih, dan B. S. (2014). Implementasi Kurikulum 2013 Konsep \& Penerapannya. Kota Pena.

Kamiludin, K., \& Suryaman, M. (2017). Problematika pada pelaksanaan penilaian pembelajaran Kurikulum 2013. Jurnal Prima Edukasia, 5(1), 58-67. https://doi.org/10.21831/jpe.v5i1.8391

Kognitif, P. K. (2016). Pengaruh Kemampuan Kognitif, Kreativitas, Dan Memecahkan Masalah Terhadap Sikap Ilmiah Siswa Sd. Journal of Primary Education, 5(1), 10-20. https://doi.org/10.15294/jpe.v5i1.12887

Kunandar. (2015). Penilaian Autentik (Penilaian Hasil Belajar Peserta didik berdasarkan Kurikulum 2013.

Maghfiroh, F., Sholikhah, H. A., \& Sofyan, F. A. (2019). Upaya Guru dalam Mengatasi Kesulitan Belajar Membaca Siswa. JIP: Jurnal Ilmiah PGMI, 5(1), 95-105. https://doi.org/10.19109/jip.v5i1.3272

Muhith, Abd. (2018). Problematika Pembelajaran Tematik Terpadu di Min III Bondowoso. Indonesian Journal of Islamic Teaching, 1(1), 45-61.

Mulyasa. (2016). Pengembangan dan Implementasi Kurikulum 2013. PT Remaja Rosdakarya.

Pane, A., \& Darwis Dasopang, M. (2017). Belajar Dan Pembelajaran. FITRAH:Jurnal Kajian Ilmu-Ilmu Keislaman, 3(2), 333. https://doi.org/10.24952/fitrah.v3i2.945 
Pratiwi, I. M., \& Ariawan, V. A. N. (2017). Analisis Kesulitan Siswa Dalam Membaca Permulaan Di Kelas Satu Sekolah Dasar. Sekolah Dasar: Kajian Teori Dan Praktik Pendidikan, 26(1), 69-76. https://doi.org/10.17977/um009v26i12017p069

Rini Kristiantari, Mg. (2015). Analisis Kesiapan Guru Sekolah Dasar dalam Mengimplementasikan Pembelajaran Tematik Integratif Menyongsong Kurikulum 2013. JPI (Jurnal Pendidikan Indonesia), 3(2), 460-470. https://doi.org/10.23887/jpi-undiksha.v3i2.4462

Rosalin, E. (2008). Guru Dalam Meningkatkan Daya Pikir Siswa. Jurnal Manajemen Pendidikan, 8(2).

Sekolah, D. I., \& Kejuruan, M. (2019). Pengaruh suasana kelas terhadap hasil belajar pembuatan busana industri di sekolah menengah kejuruan. 5(1), 160-166.

Setiawan, A. R. (2019). Pembelajaran Tematik Berorientasi Literasi Saintifik. Jurnal Basicedu, 4(1), 51-69. https://doi.org/10.31004/basicedu.v4i1.298

Sugiyono. (2017). Metode Penelitian Kuantitatif Kualitatif dan R\&D. Alfabeta.

Syarifudin, A. S. (2020). Impelementasi Pembelajaran Daring Untuk Meningkatkan Mutu Pendidikan Sebagai Dampak Diterapkannya Social Distancing. Jurnal Pendidikan Bahasa Dan Sastra Indonesia Metalingua, 5(1), 31-34. https://doi.org/10.21107/metalingua.v5i1.7072

W, F. D. (2013). The Importance of Knowing Student Learning Styles in Classroom Learning Activities. Erudio Journal of Educational Innovation, 2(1).

Wahyono, P., Husamah, H., \& Budi, A. S. (2020). Guru profesional di masa pandemi COVID-19: Review implementasi, tantangan, dan solusi pembelajaran daring. Jurnal Pendidikan Profesi Guru, 1(1), 51-65.

Wahyuni, H. T., Setyosari, P., \& Kuswandi, D. (2016). Implementasi Pembelajaran Tematik Kelas 1 Sd. Edcomtech, 1(2), 129-136.

Yeni, E. M., \& Almuslim, U. (2015). Kesulitan Belajar Matematika di Sekolah Dasar. Jupendas, 2(2), 1-10.

Yulyani, Y., Kazumaretha, T., Arisanti, Y., Fitria, Y., \& Desyandri, D. (2020). Implementasi Kompetensi Pedagogik Guru Dalam Pembelajaran Tematik Di Sekolah Dasar. School Education Journal Pgsd Fip Unimed, 10(2), 184. https://doi.org/10.24114/sejpgsd.v10i2.18545 